\title{
Human health risk and ecological risk assessment of metals in fishes, shrimps and sediment from a tropical river
}

\author{
S. Giri $\cdot$ A. K. Singh
}

Received: 10 May 2013/Revised: 4 November 2013/Accepted: 21 April 2014/Published online: 3 May 2014

(C) Islamic Azad University (IAU) 2014

\begin{abstract}
Concentrations of $\mathrm{Cd}, \mathrm{Cu}, \mathrm{Pb}, \mathrm{Ni}, \mathrm{Zn}$ and $\mathrm{Cr}$ were estimated using inductively coupled plasma-mass spectrometry in sediment, water, fish and shrimp collected from the Subarnarekha River. Fish species Mystus gulio, Puntius conchonius, Labeo calbasu, Labeo rohita and Labeo bata, while the shrimp species Penaeus indicus, were used for the study. The range of $\mathrm{Cd}, \mathrm{Cu}, \mathrm{Pb}, \mathrm{Ni}, \mathrm{Zn}$ and $\mathrm{Cr}$ in all the samples was found to be $0.004-0.85$, $0.75-145.2, \quad 0.03-0.41, \quad 1.25-21.5, \quad 12.4-109.5$ and $0.22-11.36 \mathrm{mg} \mathrm{kg}^{-1}$ fresh, respectively. The concentrations of metals in the fish and shrimp exceed the limits of Indian and international standards for food for $\mathrm{Cu}, \mathrm{Ni}, \mathrm{Cd}$ and $\mathrm{Zn}$ in some samples. Higher concentrations of the metals were observed in the shrimp as compared to fish samples. The calculated daily intakes of the metals through the consumption of fish and shrimps ranged from 0.30 to $27.0 \%$ of the corresponding tolerable limits suggested by the Joint FAO/WHO Expert Committee on Food Additives. The mean target hazard quotient values for the 6 metals were below 1 for all the samples; however, the maximum was more than 1 for shrimp $\mathrm{Cu}$ and $\mathrm{Cr}$. The results indicated that the concentration of the metals in shrimps at some locations was alarming and pose an appreciable hazard risk on human health. Potential ecological risk analysis of sediment indicated that most of the sites posed moderate ecological risk with $\mathrm{Cd}$ posing a considerable risk at all the sites.
\end{abstract}

S. Giri $(\bowtie) \cdot$ A. K. Singh

Geo-Environment Division (EMG), Central Institute of Mining and Fuel Research, Dhanbad 826015, India

e-mail: soma0307@gmail.com
Keywords Daily intake - Hazard index - Potential ecological risk - Subarnarekha River · Target hazard quotient

\section{Introduction}

Due to their toxicity and long persistence, metal contamination is a serious threat to aquatic environment. Metals occur in the environment both as a result of natural processes and as pollutants from human activities (GarciaMontelongo et al. 1994; Jordao et al. 2002). Sediments act as sinks and sometimes potential sources of various contaminants in aquatic systems. The accumulation and distribution of metals within the aquatic environment are governed by complex processes of material exchange affected by various anthropogenic activities and/or natural processes, including riverine or atmospheric inputs, coastal and seafloor erosion, biological activities, water drainage, and discharge of urban and industrial wastewaters (Christophoridis et al. 2009). Suspended sediments adsorb pollutants from the water, thus lowering their concentration in the water column although they may be released into the water column in response to certain disturbances (Agarwal et al. 2005), causing potential threat to ecosystems (Chow et al. 2005; Hope 2006). Bottom sediments also provide habitats and a food source for benthic fauna. Thus, pollutants may be directly or indirectly toxic to the aquatic flora and fauna.

Some metals like $\mathrm{Zn}$ and $\mathrm{Cu}$, which are required for metabolic activity in organisms, lie in the narrow "window" between their essentiality and toxicity. Other heavy metals like $\mathrm{Cd}$ and $\mathrm{Pb}$ may exhibit extreme toxicity even at low levels under certain conditions, thus necessitating regular monitoring of sensitive aquatic environments 
(Fergusson 1990; Peerzada et al. 1990; Cohen et al. 2001). Fish and shrimps could be sampled more frequently and easily in comparison with other water creatures (Moiseenko and Kudryavtseva 2001) and are regarded as significant indicator in aquatic systems for the estimation of water pollution (Canli and Atli 2003; Brumbaugh et al. 2005; Fernandes et al. 2007). In addition, fish are most indicative factors in freshwater systems, for the estimation of trace metal pollution and risk potential of human consumption (Rashed 2001). For the normal metabolism of fish, the essential metals like copper and zinc must be taken up from water, food or sediment. However, similar to the route of essential metals, non-essential ones are also taken up by fish and accumulate in their tissues (Canli and Atli 2003; Yilmaz 2006). The shellfish (particularly the shrimp) is a major exportable item of countries like India and therefore keenly related to economy of the country (Subramanian and Sukumar 1988). Hence, it is important to investigate the levels of metals in these organisms to assess whether the concentration is within the permissible level and will not pose any hazard to the consumers (Sivaperumal et al. 2007; Uysal et al. 2008; Palaniappan and Karthikeyan 2009).

Several methods have been proposed for estimation of the potential risks to human health of heavy metals in fishes. These methods typically are based on the target hazard quotient (THQ). Although the THQ-based risk assessment method does not provide a quantitative estimate of the probability of an exposed population experiencing an adverse health effect, it does provide an indication of the risk level associated with pollutant exposure. This method of risk estimation has recently been used by many researchers (Chien et al. 2002; Wang et al. 2005) and has been shown to be valid and useful. This non-cancer risk assessment method has been applied in this study.

Consequently, an analysis of the distribution of heavy metals in sediments adjacent to populated areas could be used to investigate anthropogenic impacts on ecosystems and would assist in the assessment of risks posed by human waste discharges ( $\mathrm{Hu}$ et al. 2002; de Mora et al. 2004; Zheng et al. 2008). Under certain conditions, these metals may accumulate to a toxic concentration level which may lead to ecological damage (Jefferies and Freestone 1984). Methods used to evaluate the ecological risk posed by heavy metals in sediments include calculation of the index of geoaccumulation (Porstner 1989), the potential ecological risk index (Håkanson 1980) and the excess after regression analysis (ERA) (Hilton et al. 1985), among which the first two indices are the most popular.

The analysis of the water, sediment and aquatic beings such as fish and shrimps could indicate the level and the tendency of the pollution. This is important not only for protection of the environment but for the quality of the fish in the water. The study is carried out in Subarnarekha River which flows through the East Singhbhum district, which is one of India's important mineralized and industrialized areas known for ore mining, steel production, power generation, cement production and other related activities. Considering the above facts, the present study was taken up with the objectives to evaluate the metal concentrations in the surface water, sediment, fish and shrimp of the Subarnarekha River and assessment of the ecological risk of metals in the sediment and health risk of metals in the fish and shrimp of the river. To achieve the objectives, sampling of water, sediment, fish and shrimp was carried out during September 2011 from the river.

\section{Materials and methods}

\section{Description of the study area}

The Subarnarekha River is the eighth river of India by its flow (12.37 billion $\mathrm{m}^{3}$ per year) and length. The River Subarnarekha is a rain fed river originating near Nagri village $\left(23^{\circ} 18^{\prime} 02^{\prime \prime} \mathrm{N}, 85^{\circ} 11^{\prime} 04^{\prime \prime} \mathrm{E}\right)$ in the Ranchi district runs through several major cities and towns such as Jamshedpur, Chaibasa, Ranchi, Bhadrak, etc., covering a distance of about $400 \mathrm{~km}$. It finally joins the Bay of Bengal at Kirtania port $\left(21^{\circ} 33^{\prime} 18^{\prime \prime} \mathrm{N}, 87^{\circ} 23^{\prime} 31^{\prime \prime} \mathrm{E}\right)$ in Orissa. Before falling in the Bay of Bengal, the river flows through Ranchi, Saraikela and East Singhbhum districts of Jharkhand, West Midnapore district of West Bengal and Baleshwar district of Orissa. Of its total length, $269 \mathrm{~km}$ lies in Jharkhand, $64 \mathrm{~km}$ in West Bengal and 62 in Orissa. The Subarnarekha basin covers an area of $19,300 \mathrm{~km}^{2}$. This area is nearly $0.6 \%$ of the total national river basin area and yields $0.4 \%$ of the country's total surface water resources. The six sampling stations taken up for the study are given in Fig. 1. The sample codes in the figure are given as 1, 2, 3, 4, 5 and 6 for Barabinda, Tatanagar, Mosabani, Gopiballavpur, Mahapal and Kirtania, respectively. Tatanagar is situated in highly industrialized region, while Mosabani is located in a copper mining area. Barabinda, Gopiballavpur and Mahapal are less polluted sites. Kirtania is the mouth of the river where it meets the Bay of Bengal.

Sampling collection and preparation

A total of 108 fresh fish and shrimp were collected consisting of 5 species of fish and 1 species of shrimp from 6 different locations along the Subarnarekha River. The species of fish that were used for the study were Mystus gulio, Puntius conchonius, Labeo calbasu, Labeo rohita and Labeo bata, while the shrimp species was Penaeus 


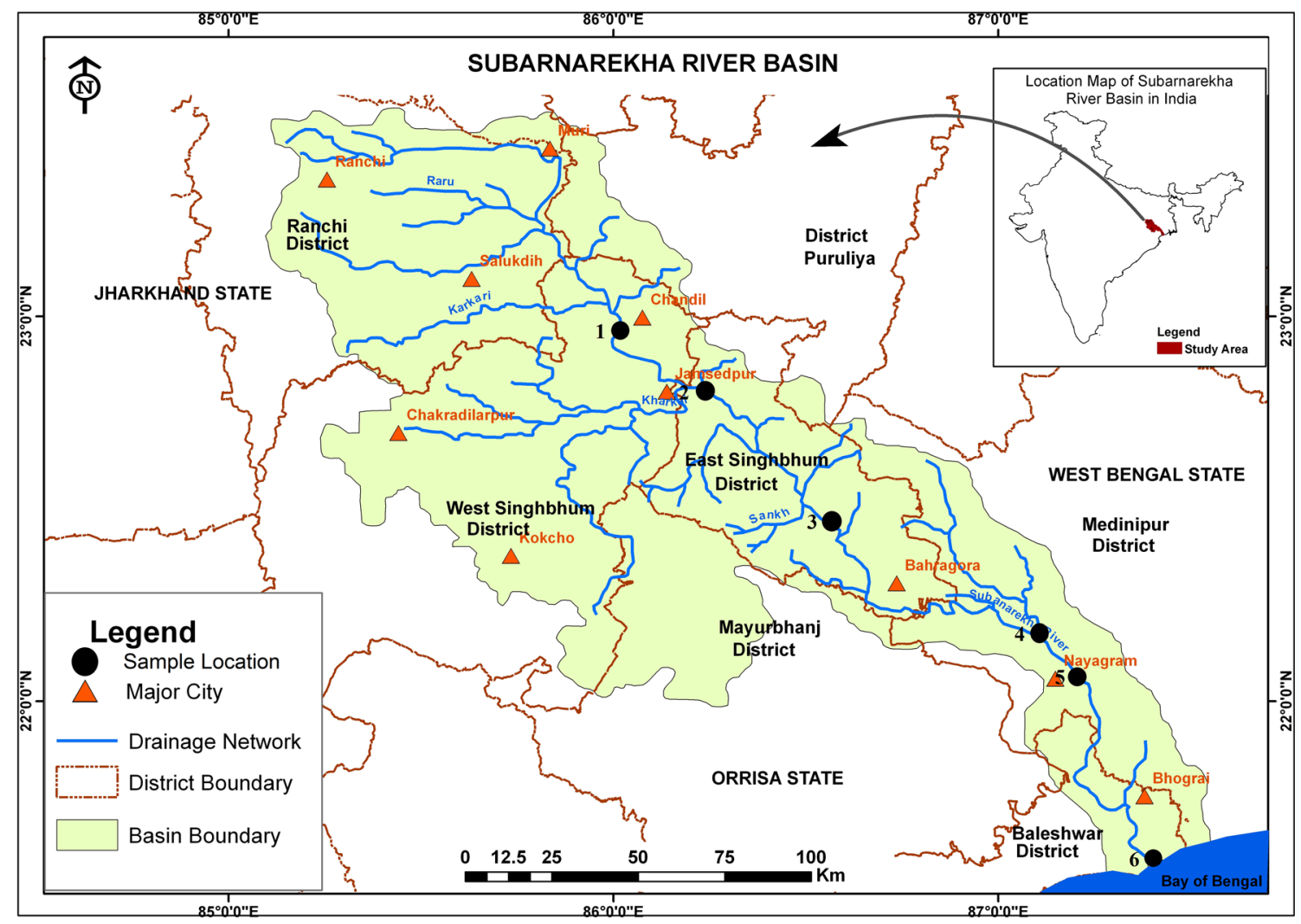

Fig. 1 Map of the study area with sampling locations

indicus. Only two commonly found species, viz. M. gulio and $L$. rohita were collected from the high saline region of Kirtania site. The samples were collected from fishermen catch. The species selected were found throughout the river basin and constituted the most important meal species for the local populations. Each species from each location was collected in triplicates. Fish and shrimp samples were placed in an ice box and transported to the laboratory. In the laboratory, the samples were cleaned up with tap water and deionized water and the dorsal muscle samples of each fish were removed for metal analysis. The muscle is preferred because it is a major target tissue for metal storage (Rejomon et al. 2010) and is the main edible part of the fish. Therefore, metal assessment in muscle would determine status of public health risk (Reinfelder et al. 1998). In case of shrimps, the exoskeleton was removed and the soft abdomen muscle was taken for analysis discarding the cephalothorax and tail portions. The soft tissues of fish and shrimp were thoroughly washed with Millipore water and dried to a constant weight at $105{ }^{\circ} \mathrm{C}$ in acid-cleaned Petri dishes. Pulverization and homogenization were achieved by grinding the tissue samples in mortar and pestle (UNEP/ FAO/IAEA/IOC 1984). Two grams of muscle samples were digested using a mixture $(7: 3 \mathrm{v} / \mathrm{v})$ of $65 \%$ nitric acid and $70 \%$ perchloric acid (AR grade) on a hot plate at $80-90^{\circ}$ until the sample becomes clear. After digestion, the samples were dissolved in $5 \mathrm{ml}$ of $15 \% \mathrm{HNO}_{3}$ (Protasowicki 1985). All the digested solutions were filtered through quantitative Whatman filter paper (No. 1) and diluted to $25 \mathrm{ml}$ in the volumetric flask with ultrapure water. In parallel, blank samples and reference materials (DOLT-4) were run in triplicate in each analytical series.

Sediment and water samples were collected from the site of collection of fish samples. From each location, sediment and water were collected in five replicates. Bed surficial sediment samples were collected with a plastic spade by scooping from the upper $3-5 \mathrm{~cm}$ of river bed representing contemporary deposits at a water depth of about $50 \mathrm{~cm}$. Then, the sediments were packed and sealed in polyethylene bags and brought to the laboratory, where they were air dried at room temperature $\left(25-30^{\circ} \mathrm{C}\right)$. Samples were mixed well by coning and quartering method and about $100 \mathrm{~g}$ of the sample was taken. The samples were transferred into a porcelain dish and dried in an oven at $110{ }^{\circ} \mathrm{C}$ for $24 \mathrm{~h}$. The samples were then powdered in a dry mortarpestle and sieved through standard sieve of 200 mesh size. The samples were then preserved for the digestion and further analysis of metals. Collected samples were taken and subjected to digestion in microwave by the method 3052 as given by USEPA (1996). $0.25 \mathrm{~g}$ of sample was 
Table 1 Metal concentration in certified reference material (Dogfish Liver DOLT-4 and Estuarine sediment NIST-1646a)

\begin{tabular}{|c|c|c|c|c|c|c|}
\hline \multirow[t]{2}{*}{ Element } & \multicolumn{3}{|l|}{ Dogfish liver DOLT-4 } & \multicolumn{3}{|c|}{ Estuarine sediment NIST-1646a } \\
\hline & $\begin{array}{l}\text { Certified concentration } \\
\left(\mathrm{mg} \mathrm{kg}^{-1}\right)\end{array}$ & $\begin{array}{l}\text { Observed concentration } \\
\left(\mathrm{mg} \mathrm{kg}^{-1}\right)\end{array}$ & $\begin{array}{l}\text { Recovery } \\
(\%)\end{array}$ & $\begin{array}{l}\text { Certified concentration } \\
\left(\mathrm{mg} \mathrm{kg}^{-1}\right)\end{array}$ & $\begin{array}{l}\text { Observed concentration } \\
\left(\mathrm{mg} \mathrm{kg}^{-1}\right)\end{array}$ & $\begin{array}{l}\text { Recovery } \\
(\%)\end{array}$ \\
\hline $\mathrm{Cd}$ & $24.33 \pm 0.8$ & $23.45 \pm 0.4$ & 96.4 & 0.148 & $0.131 \pm 0.08$ & 88.5 \\
\hline $\mathrm{Cu}$ & $31.2 \pm 1.1$ & $32.54 \pm 0.81$ & 104.3 & 10.01 & $11.2 \pm 0.7$ & 112.0 \\
\hline $\mathrm{Pb}$ & $0.160 \pm 0.04$ & $0.170 \pm 0.05$ & 106.2 & 11.7 & $11.07 \pm 0.62$ & 94.6 \\
\hline $\mathrm{Ni}$ & $0.97 \pm 0.11$ & $0.910 \pm 0.13$ & 93.8 & 23.0 & $21.74 \pm 1.1$ & 94.5 \\
\hline $\mathrm{Zn}$ & $116.0 \pm 6.0$ & $109.7 \pm 2.3$ & 94.6 & 48.9 & $42.69 \pm 1.4$ & 87.3 \\
\hline $\mathrm{Cr}$ & $\mathrm{NA}^{\mathrm{a}}$ & & & 40.9 & $38.17 \pm 1.2$ & 93.3 \\
\hline
\end{tabular}

${ }^{\text {a }}$ NA not available

taken and $4.5 \mathrm{ml} \mathrm{HNO}_{3}, 2 \mathrm{ml} \mathrm{HF}, 1 \mathrm{ml} \mathrm{HCl}$ and $0.5 \mathrm{ml}$ $\mathrm{H}_{2} \mathrm{O}_{2}$ was added. The samples were digested in microwave (Anton Paar) and filtered, and the volume was made up to $50 \mathrm{ml}$ by adding $2 \%(\mathrm{v} / \mathrm{v})$ nitric acid. Aliquots were preserved for the analysis of metals. Water samples for metal analysis were collected, filtered with Millipore filter paper(pore size- $0.45 \mu \mathrm{m}$ ) and preserved by lowering the $\mathrm{pH}$ to $<2$ by addition of $6 \mathrm{~N}$ ultrapure nitric acid (Radojevic and Bashkin 1999).

\section{Determination of metals}

Concentrations of $\mathrm{Cd}, \mathrm{Cu}, \mathrm{Pb}, \mathrm{Ni}, \mathrm{Zn}$ and $\mathrm{Cr}$ were determined in water, sediment, fish and shrimp using inductively coupled plasma-mass spectrometry (ICP-MS, Perkin Elmer Elan DRC-e.). A calibration blank and an independent calibration verification standard was analyzed every 15 samples to confirm the calibration status of the ICP-MS. Metal concentrations were expressed as $\mathrm{mg} \mathrm{kg}^{-1}$ fresh weight of fish tissue. Matrix interference (Blank) was $<1 \%$ for all elements. Recovery rates of metals spiked in fish muscles, water and sediments ranged from 88 to $110 \%$. Triplicates of samples analysis yielded relative percent differences of $<5 \%$.

\section{Validation methodology}

The method of analysis was validated using DOLT-4 certified reference material (dogfish liver), supplied by the National Research Council, Canada, NRC, Division of Chemistry and NIST-1646a standard reference material (Estuarine sediment) supplied by National Institute of Standards and Technology (NIST), USA. The validation results are shown at Table 1 . The accuracy and precision were checked by analyzing the certified reference material under the same conditions (Table 1 ). The $\%$ of recovery varied from 93.8 to 106.2 in case of fish and 87.3-112 in case of sediment.
Statistical analysis of the data

For each metal, the distribution of the combined data of the fish was verified by the curve of accumulated frequency (Miller and Miller 1989). As usually observed in environmental samples, the concentrations of the metals were better represented by the lognormal distribution and the central tendency thus is represented by the geometric average (Wayne 1990).

Calculation of estimated daily intake (EDI)

Taking the geometric mean concentration of the metals in $\mathrm{mg} \mathrm{kg}{ }^{-1}$ fresh and per day consumption of $15 \mathrm{~g}$ of fish (based on interview of the local consumers) the daily intake was evaluated for the metals. The estimated daily intake (EDI) of metals depends on both of the metal concentrations in fish and the consuming amounts of fish. The EDI value for an adult was calculated with the Eq. (1) according to Song et al. 2009.

$\mathrm{EDI}=\frac{C_{\text {metal }} \times W_{\text {fish }}}{B_{w}}$

where EDI represents the estimated daily intake of metal through the consumption of fish for an adult (in micrograms per kilogram per day), $C_{\text {metal }}$ is the concentration of metal in fish (in micrograms per gram, fresh weight), $W_{\text {fish }}$ represents the daily consumption of fish (in grams per day, fresh weight), and $B_{w}$ is the body weight of an adult (in kilogram). The average value of $B_{w}$ used was $52 \mathrm{~kg}$ for Indian man (Jain et al. 1995; Dang et al. 1996). In the present study, the value of $W_{\text {fish }}$ was $15.0 \mathrm{~g} \mathrm{day}^{-1}$ was obtained through a formal survey conducted in the study area. An interview of 30 persons of 30- to 50-year agegroup was conducted at each location of the six locations regarding their daily consumption rate of fish. Each person represents a household having $\geq 5$ individuals, and thus, a total of 150 persons were effectively interviewed. An 
average consumption rate of fish per person per day was calculated.

Risk from the intake of metals through ingestion: target hazard quotient

Several methods have been proposed to estimate the potential risks of toxic metals on human health, in which the THQ and hazard index (HI), proposed by the USA Environmental Protection Agency (USEPA 1989), have been recognized as one of the reasonable indexes for the evaluation associated with the intake of metals by consuming the contaminated foods (Hough et al. 2004; Chary et al. 2008). This is the ratio of the EDI (milligrams per kilogram body weight per day) of a chemical to a reference dose $\left(R_{f} D\right.$, milligrams per kilogram per day) defined as the maximum tolerable daily intake of a specific metal that does not result in any deleterious health effects (Eq. 2) (USEPA 1989):

$\mathrm{THQ}=\mathrm{EDI} / R_{f} D$

If the value of THQ is above 1 (i.e., THQ $>1$ ), this means that the exposed population via the consumption of contaminated foods is likely to experience obvious deleterious effects. The higher the THQ value is the higher will be the probability of the hazard risk on human body.

For the risk assessment of multiple metals containing in fish, a total HI was employed by summing all the calculated $\mathrm{THQ}_{i}$ values of metals as described in Eq. (3) (USEPA 1989).

$\mathrm{HI}=\sum_{i=1}^{n} \mathrm{THQ}_{i}$

where $\mathrm{THQ}_{i}$ is the target hazard quotient of an individual element of metals, $\mathrm{HI}$ is the total hazard index for all the six metals studied in the present study, and $n$ is 6 .

Assessment of potential ecological risk

Håkanson (1980) developed a methodology to assess ecological risks for aquatic pollution control. The methodology is based on the assumption that the sensitivity of the aquatic system depends on its productivity. The potential ecological risk index $\left(R_{I}\right)$ was introduced to assess the degree of heavy metal pollution in sediments, according to the toxicity of heavy metals and the response of the environment:

$$
\begin{aligned}
& R_{I}=\Sigma E_{r}^{i} \\
& E_{r}^{i}=T_{r}^{i} C_{f}^{i}
\end{aligned}
$$

$C_{f}^{i}=C_{n}^{i} / C_{0}^{i}$

where $R_{I}$ is calculated as the sum of all risk factors for heavy metals in sediments, $E_{r}^{i}$ is the monomial potential ecological risk factor, $T_{r}^{i}$ is the toxic response factor for a given substance, which accounts for the toxic and sensitivity requirement, and the values for $\mathrm{Cd}, \mathrm{Cu}, \mathrm{Pb}, \mathrm{Ni}, \mathrm{Zn}$ and $\mathrm{Cr}$ are 30, 5, 5, 5, 1 and 2, respectively (Hilton et al. 1985; Wang et al. 2011). $C_{f}^{i}$ is the contamination factor, $C_{n}^{i}$ is the concentration of metals in the sediment, and $C_{0}^{i}$ is a reference value for metals. Due to lack of relevant background data of unpolluted sediment in the study area, the average sediment background values in India which are $0.3,28,11.2,37,16$ and $87 \mathrm{mg} \mathrm{kg}^{-1}$ for $\mathrm{Cd}, \mathrm{Cu}, \mathrm{Pb}, \mathrm{Ni}, \mathrm{Zn}$ and $\mathrm{Cr}$, respectively, (Subramanian et al. 1985) were adopted in the study.

According to Gan et al. (2000), the potential ecological risk of coastal sediments posed by heavy metals can be classified into the following categories:

Low risk: $E_{r}^{i}<30 ; R_{I}<100$

Moderate risk: $30 \leq E_{r}^{i}<50 ; 100 \leq R_{I}<150$ :

Considerable risk: $50 \leq E_{r}^{i}<100 ; 150 \leq R_{I}<200$ :

Very high risk: $100 \leq E_{r}^{i}<150 ; 200 \leq R_{I}<300$ :

Disastrous risk: $E_{r}^{i} \geq 150 ; R_{I} \geq 300$.

\section{Results and discussion}

Distribution of metals in fish and shrimp

The results of the metal analysis are provided in Table 2 . The average concentration of triplicate samples of each species is given alongside each species in the Table. The range of $\mathrm{Cd}, \mathrm{Cu}, \mathrm{Pb}, \mathrm{Ni}, \mathrm{Zn}$ and $\mathrm{Cr}$ of all the samples was found to be $0.004-0.85,0.75-145,0.03-0.41,1.25-21.5$, $12.4-110$ and $0.22-11.4 \mathrm{mg} \mathrm{kg}^{-1}$ fresh, respectively. Highest concentration of $\mathrm{Zn}$ and $\mathrm{Cr}$ was found in $P$. indicus from Tatanagar, while for $\mathrm{Cd}, \mathrm{Cu}, \mathrm{Ni}$ and $\mathrm{Pb}$, it was $P$. indicus collected from Mosabani. The concentrations of metals in the fish and shrimp exceeded the limits of Indian standards for food (Awasthi 2000) for $\mathrm{Ni}$ and $\mathrm{Zn}$ (1.5 and $50 \mathrm{mg} \mathrm{kg}^{-1}$, respectively) in more than $50 \%$ of the samples. In $10 \%$ of the samples, the concentration of $\mathrm{Cu}$ also exceeded the Indian limit of $30 \mathrm{mg} \mathrm{kg}^{-1}$. While comparing with international standards, levels of $\mathrm{Pb}$ were well below thresholds of concern, whereas $\mathrm{Cd}, \mathrm{Cu}$ and $\mathrm{Zn}$ were above the acceptable limits for human consumption (i.e., 40.0, $30.0,0.5$ and $0.5 \mathrm{mg} \mathrm{kg}^{-1}$, fresh weight for $\mathrm{Zn}, \mathrm{Cu}, \mathrm{Cd}$ and $\mathrm{Pb}$, respectively) set by the FAO (1983) food standards for 
Table 2 Metal concentration of fish and shrimp $\left(\mathrm{mg} \mathrm{kg}^{-1}\right)$ collected from Subarnarekha River of India (each value is average of three samples)

\begin{tabular}{|c|c|c|c|c|c|c|c|}
\hline Locations & Species & $\mathrm{Cd}$ & $\mathrm{Cu}$ & $\mathrm{Pb}$ & $\mathrm{Ni}$ & $\mathrm{Zn}$ & $\mathrm{Cr}$ \\
\hline \multirow[t]{6}{*}{ Barabinda (sample code 1 ) } & P. indicus & 0.051 & 21.2 & 0.159 & 14.5 & 30.8 & 1.44 \\
\hline & M. gulio & 0.005 & 0.75 & 0.327 & 3.36 & 67.3 & 0.695 \\
\hline & P. conchonius & 0.004 & 1.41 & 0.234 & 1.72 & 63.7 & 0.592 \\
\hline & L. calbasu & 0.006 & 2.51 & 0.266 & 2.41 & 81.9 & 0.496 \\
\hline & L. rohita & 0.004 & 5.62 & 0.145 & 1.52 & 52.1 & 0.325 \\
\hline & L. bata & 0.004 & 1.60 & 0.28 & 1.7 & 40.3 & 0.726 \\
\hline \multirow[t]{6}{*}{ Tatanagar (sample code 2) } & P. indicus & 0.621 & 29.5 & 0.325 & 21.3 & 109.5 & 11.36 \\
\hline & M. gulio & 0.026 & 1.17 & 0.256 & 5.53 & 77.5 & 0.961 \\
\hline & P. conchonius & 0.029 & 5.16 & 0.146 & 3.40 & 89.4 & 1.279 \\
\hline & L. calbasu & 0.005 & 1.48 & 0.085 & 1.73 & 99.1 & 0.68 \\
\hline & L. rohita & 0.005 & 7.68 & 0.325 & 3.42 & 79.3 & 1.051 \\
\hline & L. bata & 0.23 & 2.96 & 0.359 & 3.45 & 65.2 & 1.52 \\
\hline \multirow[t]{6}{*}{ Mosabani (sample code 3) } & P. indicus & 0.852 & 145.2 & 0.412 & 21.5 & 96.4 & 4.23 \\
\hline & M. gulio & 0.101 & 14.0 & 0.341 & 7.51 & 47.4 & 0.503 \\
\hline & P. conchonius & 0.063 & 10.6 & 0.237 & 13.9 & 81.3 & 1.397 \\
\hline & L. calbasu & 0.008 & 13.5 & 0.096 & 15.2 & 75.3 & 0.512 \\
\hline & L. rohita & 0.098 & 20.8 & 0.136 & 4.57 & 49.3 & 0.826 \\
\hline & L. bata & 0.51 & 46.4 & 0.214 & 4.36 & 54.4 & 0.745 \\
\hline \multirow[t]{6}{*}{ Gopiballavpur (sample code 4) } & P. indicus & 0.045 & 14.3 & 0.063 & 5.36 & 12.4 & 1.05 \\
\hline & M. gulio & 0.039 & 1.26 & 0.091 & 3.01 & 52.1 & 0.577 \\
\hline & P. conchonius & 0.021 & 1.25 & 0.045 & 5.26 & 63.3 & 0.985 \\
\hline & L. calbasu & 0.006 & 1.26 & 0.054 & 10.2 & 52.4 & 0.412 \\
\hline & L. rohita & 0.054 & 5.32 & 0.112 & 1.32 & 35.6 & 0.254 \\
\hline & L. bata & 0.14 & 19.6 & 0.025 & 2.59 & 52.1 & 1.04 \\
\hline \multirow[t]{6}{*}{ Mahapal (sample code 5) } & P. indicus & 0.052 & 10.3 & 0.052 & 5.89 & 14.3 & 0.69 \\
\hline & M. gulio & 0.027 & 1.11 & 0.081 & 2.15 & 42.6 & 0.215 \\
\hline & P. conchonius & 0.017 & 3.33 & 0.031 & 7.97 & 42.1 & 1.123 \\
\hline & L.calbasu & 0.007 & 0.97 & 0.058 & 11.5 & 48.6 & 0.547 \\
\hline & L. rohita & 0.061 & 4.25 & 0.096 & 1.25 & 42.7 & 0.314 \\
\hline & L. bata & 0.21 & 16.3 & 0.031 & 2.31 & 45.2 & 0.89 \\
\hline \multirow[t]{3}{*}{ Kirtania (sample code 6) } & P. indicus & 0.049 & 21.7 & 0.078 & 6.89 & 25.2 & 0.358 \\
\hline & M. gulio & 0.007 & 1.91 & 0.087 & 8.06 & 42.6 & 0.964 \\
\hline & L. rohita & 0.02 & 1.21 & 0.062 & 8.23 & 71.3 & 0.582 \\
\hline Geometric mean & & 0.031 & 5.16 & 0.121 & 4.68 & 52.2 & 0.784 \\
\hline Geometric standard deviation & & 4.75 & 3.85 & 2.23 & 2.26 & 1.64 & 2.14 \\
\hline
\end{tabular}

fish. A comparison with the European food standards (EC 2001), for fish ( $\mathrm{Pb}: 0.2-0.4 \mathrm{mg} \mathrm{kg}^{-1}$ and $\mathrm{Cd}$ : $0.05-0.10$ $\mathrm{mg} \mathrm{kg}^{-1}$, fresh weight), also showed that $\mathrm{Pb}$ was lower than the guidelines for the edible part of the examined fish, whereas $\mathrm{Cd}$ was above the acceptable limits for human consumption.

Table 3 provides the metal concentration in fish of this study and other rivers by various researchers. All the listed rivers are under vigorous anthropogenic influence including industries and mining, the condition similar to the Subarnarekha River. However, the metal concentrations in the tissue of fish vary among different studies. This may be attributed to differences in metal concentrations, chemical characteristics of water from which fish were sampled, ecological needs, metabolism, feeding patterns of fish, age and the season in which studies were carried out. It can be depicted from the table that the concentrations of most of the metals were higher in the Asian rivers which demonstrate that the metal contamination in the Asian rivers is of serious 
Table 3 Comparison of metals $\left(\mathrm{mg} \mathrm{kg}^{-1}\right)$ in fish samples with other river water studies

\begin{tabular}{|c|c|c|c|c|c|c|c|}
\hline Location & $\mathrm{Cd}$ & $\mathrm{Cu}$ & $\mathrm{Pb}$ & $\mathrm{Ni}$ & $\mathrm{Zn}$ & $\mathrm{Cr}$ & Reference \\
\hline Buriganga River, Bangladesh & & $3.36-6.34$ & $8.03-13.52$ & $8.25-11.21$ & & & Ahmad et al. 2010 \\
\hline Ipo stream, Nigeria & & 17.85 & 24.14 & 2.79 & & & Friday et al. 2009 \\
\hline Magani confluence, Nigeria & & 0.46 & 1.24 & & 0.09 & & Atolaye and Aremu 2007 \\
\hline Yangtze River & ND-2.0 & $0.36-18.8$ & $0.009-10.1$ & & $0.79-50.8$ & ND-0.81 & Yi et al. 2011 \\
\hline $\begin{array}{l}\text { Ogba River, Benin City, } \\
\text { Nigeria }\end{array}$ & & 3.81 & 0.25 & 0.04 & 4.27 & & $\begin{array}{l}\text { Obasohan and Eguavoen } \\
2008\end{array}$ \\
\hline Ganga, West Bengal, India & & $1.1-5.4$ & $0.006-0.02$ & & $4.9-12.2$ & & Bhattacharya et al. 2008 \\
\hline Ganga, Kolkata & 0.046 & 0.96 & 3.50 & & 12.59 & 0.077 & Aktar et al. 2011 \\
\hline Tingjiang river, China & - & 1.60 & 0.128 & 0.015 & 4.87 & 0.052 & Liu et al. 2012 \\
\hline Pearl river, China & $0.10-0.17$ & $0.06-0.35$ & $0.11-0.52$ & $0.04-0.36$ & $2.67-19.1$ & $0.09-0.36$ & Cheung et al. 2008 \\
\hline Danube river, Croatia & $0.013-0.018$ & & $0.015-0.039$ & & & & Zrnčić et al. 2012 \\
\hline Subarnarekha River, India & 0.031 & 5.16 & 0.121 & 4.68 & 52.2 & 0.784 & Present study \\
\hline
\end{tabular}

concern. However, the metal concentration in fish of the Subarnarekha River was in the range of other studies.

On analyzing the data, it can be inferred that the concentration of metals in the fish and shrimp species was related to the locations and species. The concentrations of the metals were visibly more in two locations, i.e., Tatanagar and Mosabani. Tatanagar is under the influence of intense industrialization and urbanization, while Mosabani is associated with active copper mining. Thus, almost all the metals have a pronounced effect on the fish and shrimp samples collected from these locations as compared to other locations. Mining and metallurgical industries are characterized with anthropogenic alteration of the biogeochemical cycles of elements and source of serious environmental pollution related to the emission of metals (Nriagu et al. 1998; Allen-Gil et al. 2003; Pyle et al. 2005). Several ways such as natural leaching of mine tailings, acid mine drainage and erosion from the mining areas are related to the discharge of pollutants containing metals into the surrounding environments (Moiseenko and Kudryavtseva 2001; Higueras et al. 2004; Riba et al. 2005; Mayes et al. 2010). Thus, aquatic environments are always the straight collector of metal elements from the mining sites and metallurgical industries (Tarras-Wahlberg et al. 2001; Sapkota et al. 2008). The mining effluents increase metal levels in the aquatic systems, which may impact aquatic life. Moreover, water contaminated by metal mining is the major source for metal accumulation in fish (Rashed 2001; Bervoets et al. 2005; Borgmann et al. 2007).
The sensitivity of crustaceans to metals is well documented, and the importance of shrimp for environmental monitoring studies as bioindicators of metal pollution has been emphasized by several investigators (Larsson et al. 1985; Yusof et al. 2004; Yilmaz and Yllmaz 2007). In the present study also, on comparing the metals concentration in the fish and shrimp species it can be easily conjectured that irrespective of the locations, the shrimps accumulated more metals than the fish species. Shrimps are benthic organisms that feed by stirring the sediment up and collecting very small particles of organic matter, and so they would be exposed to the metals bound to this food (FSA 2005; Pourang et al. 2005).

In the present investigation, the concentration of metals in the muscle tissues followed a trend of $\mathrm{Zn}>\mathrm{Cu}>$ $\mathrm{Ni}>\mathrm{Cr}>\mathrm{Pb}>\mathrm{Cd}$. The concentration of $\mathrm{Zn}$ in fish was highest among all the metals. This observation was similar to the observation of other workers for many species of fish in different aquatic systems (Tekin-Ozan 2008; Yilmaz and Dogan 2008). This can be attributed to the fact that $\mathrm{Zn}$ is present in many enzymes (Karadede and Unlu 2000; Alhas et al. 2009). In shrimps, the trend was little different being $\mathrm{Zn}>\mathrm{Cu}>\mathrm{Ni}>\mathrm{Cr}>\mathrm{Cd}>\mathrm{Pb}$.

Distribution of metals in water and sediment

The average concentrations of metals in surface water and bed sediment of Subarnarekha River are given in Table 4. The results depict that the range of $\mathrm{Cu}, \mathrm{Ni}, \mathrm{Zn}$ and $\mathrm{Cr}$ in the surface water in $\mu \mathrm{g} \mathrm{l}^{-1}$ is $0.48-16.5,0.82-4.57,5.22-13.2$ and 
Table 4 Average concentration of metals in surface water and bed sediment of Subarnarekha River $(n=5)$

\begin{tabular}{|c|c|c|c|c|c|c|}
\hline Locations & $\mathrm{Cd}$ & $\mathrm{Cu}$ & $\mathrm{Pb}$ & $\mathrm{Ni}$ & $\mathrm{Zn}$ & $\mathrm{Cr}$ \\
\hline \multicolumn{7}{|c|}{ (a) Surface water $\left(\mu g l^{-1}\right)$} \\
\hline Barabinda & N.D ${ }^{a}$ & 1.76 & N.D & 0.98 & 12.9 & 0.86 \\
\hline Tatanagar & N.D & 0.55 & N.D & 0.82 & 13.2 & 1.25 \\
\hline Mosabani & N.D & 16.5 & N.D & 4.57 & 12.4 & 1.16 \\
\hline Gopiballavpur & N.D & 4.6 & N.D & 2.25 & 6.42 & 0.22 \\
\hline Mahapal & N.D & 0.48 & N.D & 1.43 & 5.22 & 0.03 \\
\hline Kirtania & N.D & 7.8 & N.D & 3.68 & 5.64 & 1 \\
\hline IS 10500 limit $^{\mathrm{b}}$ & 10 & 50 & 50 & 20 & 5,000 & 50 \\
\hline WHO limits ${ }^{\mathrm{c}}$ & 3 & 2,000 & 10 & 70 & 3,000 & 50 \\
\hline \multicolumn{7}{|c|}{ (b) Sediment $\left(\mathrm{mg} \mathrm{kg}^{-1}\right)$} \\
\hline Barabinda & 0.64 & 63.9 & 83.0 & 45.5 & 126.4 & 123.2 \\
\hline Tatanagar & 0.744 & 44.4 & 65.0 & 27.7 & 182.1 & 70.6 \\
\hline Mosabani & 0.778 & 168.5 & 48.1 & 36.9 & 53.6 & 53.7 \\
\hline Gopiballavpur & 0.784 & 57.7 & 48.3 & 30.1 & 49.8 & 50.3 \\
\hline Mahapal & 0.789 & 43.2 & 37.6 & 39.2 & 59.5 & 94.0 \\
\hline Kirtania & 0.709 & 25.7 & 26.1 & 25.3 & 52.2 & 75.0 \\
\hline Indian average $^{\mathrm{d}}$ & 0.3 & 28 & 11.2 & 37 & 16 & 87 \\
\hline Shale average & 0.3 & 45 & 20 & 68 & 95 & 90 \\
\hline
\end{tabular}

${ }^{\text {a }} N D$ not detected

b IS:10500 IS 2012

c WHO 2004

d Subramanian et al. 1985

e Turekian and Wedepohl 1961

Table 5 Correlation coefficients of metals between fish and different matrices

\begin{tabular}{lcllllr}
\hline & $\mathrm{Cd}$ & $\mathrm{Cu}$ & $\mathrm{Pb}$ & \multicolumn{1}{l}{$\mathrm{Ni}$} & $\mathrm{Zn}$ & \multicolumn{1}{c}{$\mathrm{Cr}$} \\
\hline Sediment & -0.36 & $\mathbf{0 . 9 5}$ & $\mathbf{0 . 7 4}$ & -0.23 & $\mathbf{0 . 7 7}$ & -0.28 \\
Water & - & $\mathbf{0 . 6 2}$ & - & $\mathbf{0 . 6 8}$ & $\mathbf{0 . 8 4}$ & $\mathbf{0 . 6 1}$
\end{tabular}

Bold values indicate significant correlation at the 0.05 level

$0.03-1.25$, respectively. $\mathrm{Cd}$ and $\mathrm{Pb}$ were not detected in any of the samples. Comparing with WHO standards (WHO, 2004) and Indian Standards (IS:10500 2012), it can be inferred that none of the metals in any locations crossed the either limits. However, the highest concentration of $\mathrm{Cu}$ and $\mathrm{Ni}$ was found in Mosabani, while Tatanagar recorded the highest concentration of $\mathrm{Zn}$ and $\mathrm{Cr}$. Considering all the sampling locations, the range of $\mathrm{Cd}, \mathrm{Cu}, \mathrm{Pb}, \mathrm{Ni}, \mathrm{Zn}$ and $\mathrm{Cr}$ in $\mathrm{mg} \mathrm{kg}^{-1}$ in the bed sediments was found to be 0.709-2.64, 25.7-168.5, 26.1-83.0, 25.3-45.5, 49.8-182.1 and 50.3-123.2, respectively. A comparison with average Indian values of metals for sediments (Subramanian et al. 1985) and average concentration of metals in Shale (Turekian and Wedepohl 1961) depicted that almost all the locations for all the metals exceeded the values. As the study area is characterized by the presence of metal bearing formations and mining and industrial operations, it is expected to have elevated levels of metals in sediment (Forstner and Wiltman 1983; Preston and Chester 1996). The sediment accumulated more metals than the water in this study as have been observed by Besada et al. (2001), Chindah et al. (2003) and Eja et al. (2003). Sediment is the major depository of metals holding more than $99 \%$ of total amount of a metal present in the aquatic system (Odiete 1999).

Relationships between heavy metal levels in fish and in the environment

To assess the association between the different matrices, i.e., fish, water and sediment, correlations of the metals were determined between the different matrices and the coefficients are depicted in the Table 5. The results suggested a strong association of the $\mathrm{Zn}, \mathrm{Cu}, \mathrm{Ni}$ and $\mathrm{Cr}$ between the water and the fish samples and $\mathrm{Zn}, \mathrm{Pb}$ and $\mathrm{Cu}$ between sediment and fish samples. The positive correlation of metals between water and fish tissues has been reported by other studies also (Zyadah 2005; Fatma 2008). $\mathrm{Cu}, \mathrm{Zn}$ and $\mathrm{Pb}$ in the fish samples are found to be associated with the sediments. This is in accordance with other researchers (Chandra Sekhar et al. 2004; Fernandes et al. 2008; Obasohan and Eguavoen 2008; Vicente-Martorell et al. 2009). Cd was not detected in water samples, and the correlation between sediment and fish samples was not significant. This may be attributed to the fact that $\mathrm{Cd}$ is a highly mobile and potentially bioavailable metal and was primarily scavenged by non-detrital carbonate minerals, organic matter, and iron-manganese oxide minerals (Prusty et al. 1994).

Health risk and ecological risk assessment

\section{Estimation of daily intake of metals by consuming fish}

The survey method adopted for the study area showed that the average consumption of fish including shrimps per person per day is $15 \mathrm{~g}$. If the levels of metal concentrations (Table 2) recorded in this study are representative of metal concentrations in the fish and shrimps tested and consumed by the interview sample, then the EDI values of metals for an adult via the consumption of fish are shown in Table 6 . The data of provisional tolerable daily intake (PTDI) suggested by the Joint FAO/WHO Expert Committee on Food Additives (JECFA 1999, 2003) are also listed. In the present study, it may be noted that the $\mathrm{R}_{\mathrm{f}} \mathrm{D}$ of 
Table 6 Estimated dietary intakes (EDI) of metals by consuming fish and shrimp collected from Subarnarekha River in India

\begin{tabular}{|c|c|c|c|c|c|c|}
\hline \multirow[t]{2}{*}{ Species } & \multicolumn{6}{|c|}{ Heavy metals } \\
\hline & $\mathrm{Cd}$ & $\mathrm{Cu}$ & $\mathrm{Pb}$ & $\mathrm{Ni}$ & $\mathrm{Zn}$ & $\mathrm{Cr}$ \\
\hline \multicolumn{7}{|l|}{$P$. indicus } \\
\hline Concentration $^{\mathrm{a}}$ & 0.28 & 40.36 & 0.18 & 12.58 & 48.09 & 3.19 \\
\hline $\mathrm{EDI}^{\mathrm{b}}$ & 0.08 & 11.64 & 0.05 & 3.63 & 13.87 & 0.92 \\
\hline \multicolumn{7}{|l|}{ M. gulio } \\
\hline Concentration $^{a}$ & 0.03 & 3.37 & 0.20 & 4.94 & 54.92 & 0.65 \\
\hline $\mathrm{EDI}^{\mathrm{b}}$ & 0.01 & 0.97 & 0.06 & 1.42 & 15.84 & 0.19 \\
\hline \multicolumn{7}{|l|}{ P. conchonius } \\
\hline Concentration $^{\mathrm{a}}$ & 0.03 & 4.36 & 0.14 & 6.45 & 67.95 & 1.08 \\
\hline $\mathrm{EDI}^{\mathrm{b}}$ & 0.01 & 1.26 & 0.04 & 1.86 & 19.60 & 0.31 \\
\hline \multicolumn{7}{|l|}{ L. calbasu } \\
\hline Concentration $^{\mathrm{a}}$ & 0.01 & 3.95 & 0.11 & 8.20 & 71.46 & 0.53 \\
\hline $\mathrm{EDI}^{\mathrm{b}}$ & 0.00 & 1.14 & 0.03 & 2.36 & 20.61 & 0.15 \\
\hline \multicolumn{7}{|l|}{ L. rohita } \\
\hline Concentration $^{\mathrm{a}}$ & 0.04 & 8.74 & 0.16 & 2.42 & 51.8 & 0.55 \\
\hline $\mathrm{EDI}^{\mathrm{b}}$ & 0.013 & 2.52 & 0.047 & 0.697 & 14.94 & 0.16 \\
\hline \multicolumn{7}{|l|}{ L. bata } \\
\hline Concentration $^{\mathrm{a}}$ & 0.22 & 17.37 & 0.18 & 2.88 & 51.43 & 0.98 \\
\hline $\mathrm{EDI}^{\mathrm{b}}$ & 0.06 & 5.01 & 0.05 & 0.83 & 14.83 & 0.28 \\
\hline PTDI $^{\mathrm{c}}$ & 1 & 500 & 3.57 & 5 & 1,000 & 3 \\
\hline
\end{tabular}

a The mean values of heavy metal concentrations in fish and shrimp, in $\mathrm{mg} \mathrm{kg}^{-1}$ fresh

${ }^{\mathrm{b}}$ EDI values, in $\mu \mathrm{g} / \mathrm{kg}$ body wt/day

c PTDI values (in $\mu \mathrm{g} / \mathrm{kg}$ body wt/day) of all the metals were based on the data suggested by The Joint FAO/WHO Expert Committee on Food Additives (JECFA) $(1999,2003)$. The PTDI value of Cr was based on the reference dose $\left(R_{f} D\right)$ of $\mathrm{Cr}(\mathrm{VI})$ established by US Environmental Protection Agency (2011)

$3 \mu \mathrm{g} \mathrm{kg}^{-1}$ day $^{-1}$ for $\mathrm{Cr}(\mathrm{VI})$ established by USEPA (2011) is taken as the PTDI value of total $\mathrm{Cr}$ because of its unavailable PTDI data. From the EDI of the studied metals through the consumption of fish, it can be suggested that the consumption of average amounts of these fish does not pose a health risk for the consumers as the values obtained were below the FAO/WHO (1999) limits for metals intake. The present study showed that the contributions of these fish and shrimp to daily intake of $\mathrm{Cd}, \mathrm{Cu}, \mathrm{Pb}, \mathrm{Ni}, \mathrm{Zn}$ and $\mathrm{Cr}$ were $0.89,0.30,0.98,27.0,1.51$ and $7.54 \%$, respectively, of PTDI as suggested by JECFA.

Low dietary intake of $\mathrm{Pb}, \mathrm{Zn}$ and $\mathrm{Cu}$ was also observed for the fish and shrimp species, and the maximum EDI observed in M. gulio, L. calbasu and P. indicus only accounts for $1.68,2.06$, and $2.32 \%$, respectively, of the PTDI value. However, relative high EDI levels of $\mathrm{Cd}, \mathrm{Ni}$ and $\mathrm{Cr}$ are found for $P$. indicus, in which the EDI values account for 8.0, 72.6 and $30.7 \%$ of the PTDI values, respectively. The EDI value of $\mathrm{Ni}$ is quite high in all the species studied, highest being in $P$. indicus, which accounts for $72.6 \%$ of the PTDI value.

\section{Risk assessment of metals by consuming fish}

The THQ values of metals by consuming fish for an individual adult are shown in Table 7. The results showed that the total THQ values (HI) of metals range at the following sequence: $P$. indicus $>L$. bata $>P$. conchonius $>L$. calbasu $>M$. gulio $\geq L$. rohita. Because of the unavailable $R_{f} D$ data of total $\mathrm{Cr}, 3 \mu \mathrm{g} \mathrm{kg}^{-1} \mathrm{day}^{-1}$ of $R_{f} D$ value for $\mathrm{Cr}(\mathrm{VI})$ is considered as that of total $\mathrm{Cr}$ by assuming that all $\mathrm{Cr}$ in samples is $\mathrm{Cr}(\mathrm{VI})$. Under the strict criterion, the mean THQ values of $\mathrm{Cd}, \mathrm{Pb}$ and $\mathrm{Zn}$ were $<0.1$ for all the studied species; however, the maximum THQ values were calculated for the species of $P$. indicus, i.e., 0.25, 0.03, 0.31 and 0.11 , respectively, for $\mathrm{Cd}, \mathrm{Pb}, \mathrm{Ni}$ and $\mathrm{Zn}$. It can also be 
Table 7 Target hazard quotients (THQ) of metals by consuming fish and shrimp collected from Subarnarekha River in India

\begin{tabular}{|c|c|c|c|c|c|c|c|}
\hline \multirow[t]{2}{*}{ Species } & \multicolumn{7}{|l|}{ THQ } \\
\hline & $\mathrm{Cd}$ & $\mathrm{Cu}$ & $\mathrm{Pb}$ & $\mathrm{Ni}$ & $\mathrm{Zn}$ & $\mathrm{Cr}$ & $\mathrm{HI}$ \\
\hline \multicolumn{8}{|c|}{ P. indicus } \\
\hline Range & $0.013-0.25$ & $0.074-1.05$ & $0.004-0.03$ & $0.077-0.31$ & $0.012-0.11$ & $0.034-1.09$ & $0.26-2.14$ \\
\hline Mean & 0.08 & 0.29 & 0.01 & 0.18 & 0.05 & 0.31 & 0.92 \\
\hline \multicolumn{8}{|l|}{ M. gulio } \\
\hline Range & $0.001-0.03$ & $0.005-0.10$ & $0.007-0.03$ & $0.031-0.12$ & $0.041-0.07$ & $0.021-0.09$ & $0.12-0.36$ \\
\hline Mean & 0.010 & 0.024 & 0.016 & 0.071 & 0.053 & 0.063 & 0.24 \\
\hline \multicolumn{8}{|c|}{ P. conchonius } \\
\hline Range & $0.001-0.02$ & $0.009-0.08$ & $0.003-0.02$ & $0.025-0.20$ & $0.040-0.09$ & $0.057-0.13$ & $0.17-0.53$ \\
\hline Mean & 0.008 & 0.031 & 0.011 & 0.093 & 0.065 & 0.103 & 0.31 \\
\hline \multicolumn{8}{|c|}{ L. calbasu } \\
\hline Range & $0.001-0.02$ & $0.007-0.1$ & $0.004-0.02$ & $0.025-0.22$ & $0.047-0.09$ & $0.040-0.07$ & $0.20-0.45$ \\
\hline Mean & 0.002 & 0.028 & 0.009 & 0.118 & 0.069 & 0.051 & 0.28 \\
\hline \multicolumn{8}{|l|}{ L. rohita } \\
\hline Range & $0.001-0.03$ & $0.009-0.15$ & $0.005-0.03$ & $0.018-0.12$ & $0.034-0.08$ & $0.024-0.10$ & $0.14-0.38$ \\
\hline Mean & 0.013 & 0.063 & 0.013 & 0.035 & 0.050 & 0.053 & 0.23 \\
\hline \multicolumn{8}{|l|}{ L. bata } \\
\hline Range & $0.001-0.15$ & $0.012-0.33$ & $0.002-0.03$ & $0.025-0.06$ & $0.039-0.06$ & $0.07-0.15$ & $0.17-0.69$ \\
\hline Mean & 0.063 & 0.125 & 0.015 & 0.042 & 0.049 & 0.095 & 0.39 \\
\hline
\end{tabular}

Table 8 Heavy metal potential ecological risk indexes of the sediment of the Subarnarekha River

\begin{tabular}{llrllrllr}
\hline Locations & \multicolumn{1}{l}{$E_{r}^{i}$} & & & & \multicolumn{3}{c}{$R_{I}$} \\
\cline { 2 - 6 } & $\mathrm{Cd}$ & $\mathrm{Cu}$ & $\mathrm{Pb}$ & $\mathrm{Ni}$ & $\mathrm{Zn}$ & $\mathrm{Cr}$ & \\
\hline Barabinda & $\mathbf{6 4}$ & 11.41 & $\mathbf{3 7 . 0 5}$ & 6.14 & 7.90 & 2.83 & $\mathbf{1 2 9 . 3}$ \\
Tatanagar & $\mathbf{7 4 . 4}$ & 7.93 & 29.02 & 3.74 & 11.38 & 1.62 & $\mathbf{1 2 8 . 1}$ \\
Mosabani & $\mathbf{7 7 . 8}$ & $\mathbf{3 0 . 0 9}$ & 21.46 & 4.98 & 3.35 & 1.23 & $\mathbf{1 3 8 . 9}$ \\
Gopiballavpur & $\mathbf{7 8 . 4}$ & 10.30 & 21.57 & 4.06 & 3.11 & 1.16 & $\mathbf{1 1 8 . 6}$ \\
Mahapal & $\mathbf{7 8 . 9}$ & 7.71 & 16.77 & 5.30 & 3.72 & 2.16 & $\mathbf{1 1 4 . 6}$ \\
Kirtania & $\mathbf{7 0 . 1}$ & 4.59 & 11.66 & 3.42 & 3.26 & 1.72 & 94.7 \\
\hline
\end{tabular}

$E_{r}^{i}$ is the individual heavy metal potential ecological risk index, $R_{I}$ is the total heavy metal potential ecological risk index; bold types indicates the sample sites with moderate or considerable ecological risk

noted that the maximum THQ levels of $\mathrm{Cu}$ and $\mathrm{Cr}$ were more than 1, i.e., in $P$. indicus, but their mean values were totally far below 1 .

THQ value proposed by USA EPA is an integrated risk index by comparing the ingestion amount of a pollutant with a standard reference dose and has been widely used in the risk assessment of metals in contaminated foods (Storelli 2008). The THQ value has been recognized as one of the reasonable parameters for the risk assessment of metals associated with the consumption of contaminated fish and shellfish (Chien et al. 2002; Zheng et al. 2007; Storelli 2008). In the present study, the average HI values for all the species were below 1 , which indicated that the intakes of metals by consuming these do not result in an appreciable hazard risk on human body. However, the HI value for $P$. indicus was 0.92 which is near to 1 thus indicating probable risk in consumption. Furthermore, the highest values of $\mathrm{HI}$ in case of $P$. indicus also exceeded the limit of 1 indicating potential risk to the human. The highest values of HI were in the samples collected from the locations of Tatanagar and Mosabani. This indicated potential contamination of shrimp samples with metals which may be attributed to the contribution of the high levels of these metals in aquatic environments from copper mines and urban effluents. Metals have a toxic impact, but detrimental impacts become apparent only when long-term consumption of contaminated fish and shrimp occurs. It is therefore suggested that regular monitoring of metals in fish and other aquatic organisms should be performed in order to prevent excessive buildup of these metals in the human food chain. Further investigation is recommended seasonal variability of essential and toxic metals in other consumed fish species for safeguarding human health. 


\section{Potential ecological risk assessment of sediment}

Using Eq. (4-6), the potential ecological risk indices $E_{r}^{i}$ and $R_{I}$ for each site were obtained and are listed in Table 8 . According to these data, Cd posed a considerable ecological risk at all the sites. Additionally, $\mathrm{Cu}$ and $\mathrm{Pb}$ also posed moderate ecological risks in one site each. The high ecological risks of these three heavy metals in freshwater ecosystems were consequences of their high toxic response factors.

$R_{I}$ represents the sensitivity of various biological communities to toxic substances and illustrates the potential ecological risk caused by heavy metals. Five sites out of six exhibited moderate ecological risk, the highest being at Mosabani which is under the influence of industrial and mining activities. The $R_{I}$ values were clearly related to the degree of anthropogenic disturbance. The sources of heavy metal pollution in the river are influenced by many factors, both natural and manmade.

\section{Conclusion}

Accumulation of metals by different fish and shrimp species from Subarnarekha River assumes importance due to its flowing from large-scale industrial and mining-related areas. The concentrations of metals in the fish and shrimp exceeded the limits of Indian standards for food for $\mathrm{Cu}, \mathrm{Ni}$ and $\mathrm{Zn}$ in many samples. The study also suggested that irrespective of the locations the shrimps accumulated more metals than the fish species. The results furthermore suggested a strong association of the $\mathrm{Zn}, \mathrm{Cu}, \mathrm{Ni}$ and $\mathrm{Cr}$ between the water and the fish samples and $\mathrm{Zn}, \mathrm{Pb}$ and $\mathrm{Cu}$ between sediment and fish samples. The mean THQ values of for the 6 metals were below 1 for all the samples; however, the maximum THQ was more than 1 for $P$. indicus in case of $\mathrm{Cu}$ and $\mathrm{Cr}$. Also, the total THQ value (HI) calculated was also nearing 1 for the same species which signified the potential health risk to highly exposed consumers. The shrimps, being a favorite food of people in this region, the high consumption of it can lead to chronic disorders, e.g., renal failure, bone disorders, etc., as this has high concentration of metals. As fish and shrimp are staple food for human being, the accumulation of metals exceeding the permissible limits is a serious health concern. Analysis of the potential ecological risk of sediment heavy metal concentrations showed that most sample sites in the Subarnarekha River presented a moderate ecological risk. According to the potential ecological risk index for a single regulator $\left(E_{r}^{i}\right), \mathrm{Cd}$ represented a considerable risk at all sites and a moderate risk for $\mathrm{Cu}$ and $\mathrm{Pb}$ at one site. The ecological risk for all factors $\left(R_{I}\right)$ showed that five out of six sample sites belonged in the category of moderate risk. The study thus highlighted the metal accumulation in fish and sediment of the Subarnarekha River. As the high metal availability in the river is attributed to anthropogenic origin, adequate strategies are to be adopted in order to control their presence so that the possible health hazards to different life forms including man can be prevented.

Acknowledgments The authors are grateful to Department of Science and Technology, Government of India, for providing the necessary funding for the study under the Fast Track Young Scientist Scheme \{Grant No. SR/FTP/ES-185/2010(G)\}. Also authors are thankful to the Director and Geo-Environment Division (EMG), Central Institute of Mining and Fuel Research, Dhanbad for providing the necessary laboratory facilities and other logistic support for the study.

\section{References}

Agarwal A, Singh RD, Mishra SK, Bhunya PK (2005) ANN-based sediment yield river basin models for Vamsadhara (India). Water SA 31:95-100

Ahmad MK, Islam S, Rahman S, Haque MR, Islam MM (2010) Heavy metals in water, sediment and some fishes of Buriganga River, Bangladesh. Int J Environ Res 4:321-332

Aktar MW, Sengupta D, Chowdhury A (2011) Occurrence of heavy metals in fish: a study for impact assessment in industry prone aquatic environment around Kolkata in India. Environ Monit Assess 181:51-61

Alhas E, Oymak SA, Karadede H (2009) Heavy metal concentrations in two barb, Barbus xanthopterus and Barbus rajanorum mystaceus from Ataturk Dam Lake, Turkey. Environ Monit Assess 148:11-18

Allen-Gil SM, Ford J, Lasorsa BK, Monetti M, Vlasova T, Landers DH (2003) Heavy metal contamination in the Taimyr Peninsula, Siberian Arctic. Sci Total Environ 301:119-138

Atolaye BO, Aremu MO (2007) Bioaccumulation of some trace elements in the body parts of fish species associated with soil sediment and water from "Magani" confluence in Nasarawa State, Nigeria. Elect J Environ Agric Food Chem 6:2001-2008

Awasthi SK (2000) Prevention of Food Adulteration Act No. 37 of, 1954 Central and State rules as amended for 1999. Ashoka Law House, New Delhi

Bervoets L, Knaepkens G, Eens M, Blust R (2005) Fish community responses to metal pollution. Environ Pollut 138:338-349

Besada V, Fumega J, Vaamond A (2001) Temporal trends of Cd, Cu, $\mathrm{Hg}, \mathrm{Pb}$ and $\mathrm{Zn}$ in Mussel (Mytilus galloprovinciatis) from the Spanish North Atlantic coast 1991-1999. Sci Total Environ 181:1-15

Bhattacharya AK, Mandal SN, Das SK (2008) Heavy metals accumulation in water, sediment and tissues of different edible fishes in upper stretch of Gangetic West Bengal. Trends Appl Sci Res 3:61-68 
Borgmann U, Couillard Y, Grapentine LC (2007) Relative contribution of food and water to 27 metals and metalloids accumulated by caged Hyalella azteca in two rivers affected by metal mining. Environ Pollut 145(3):753-765

Brumbaugh WG, Schmitt CJ, May TW (2005) Concentrations of cadmium, lead, and zinc in fish from mining-influenced waters of northeastern Oklahoma: sampling of blood, carcass, and liver for aquatic biomonitoring. Arch Environ Contam Toxicol 49(1):76-88

Canli M, Atli G (2003) The relationships between heavy metal (Cd, $\mathrm{Cr}, \mathrm{Cu}, \mathrm{Fe}, \mathrm{Pb}, \mathrm{Zn}$ ) levels and the size of six Mediterranean fish species. Environ Pollut 121(1):129-136

Chandra Sekhar K, Chary NS, Kamala CT, Suman Raj DS, Sreenivasa Rao A (2004) Fractionation studies and bioaccumulation of sediment-bound heavy metals in Kolleru lake by edible fish. Environ Int 29(7):1001-1008

Chary NS, Kamala CT, Raj DSS (2008) Assessing risk of heavy metals from consuming food grown on sewage irrigated soils and food chain transfer. Ecotoxicol Environ Saf 69:513-524

Cheung KC, Leung HM, Wong MH (2008) Metal concentrations of common freshwater and marine fish from the Pearl River Delta, south China. Arch Environ Contam Toxicol 54:705-715

Chien LC, Hung TC, Choang KY, Yeh CY, Mneg PJ, Shieh MJ, Ha BC (2002) Daily intake of TBT, Cu, Zn, Cd and As for fishermen in Taiwan. Sci Total Environ 285:177-185

Chindah AC, Braide SA, Osuamkpe A (2003) Levels of hydrocarbons and heavy metals in sediment and a decapods crustacean (crabUca tangeri) in the Bonny/New Calabar River Estuary, Niger Delta. Ecotoxicol Environ Saf 14:88-96

Chow TE, Gaines KF, Hodgson ME, Wilson MD (2005) Habitat and exposure modelling for ecological risk assessment: a case study for the raccoon on the Savanah River Site. Ecol Model 189:151-167

Christophoridis C, Dedepsidis D, Fytianos K (2009) Occurrence and distribution of selected heavy metals in the surface sediments of Thermaikos Gulf, N. Greece: assessment using pollution indicators. J Hazard Mater 168:1082-1091

Cohen T, Hee S, Ambrose R (2001) Trace metals in fish and invertebrates of three California coastal wetlands. Mar Pollut Bull 42:232-242

Dang HS, Jaiswal DD, Parameswaran M, Deodhar KP, Krishnamony $S$ (1996) Age dependent physical and anatomical Indian data for application in internal dosimetry. Radiat Prot Dosim 63:217-222

de Mora S, Fowler SW, Wyse E, Azemard S (2004) Distribution of heavy metals in marine bivalves, fish and coastal sediments in the Gulf and Gulf of Oman. Mar Pollut Bull 49:410-424

EC (2001) European Commision Regulation (EC) No. 466/2001 of 8 March 2001. Official Journal of the European Communities, $1.77 / 1$

Eja ME, Ogri ORA, Arikpo GE (2003) Bioconcentration of heavy metals in surface sediments from the Great kwa Rivers Estuary, Calabar, South Eastern Nigeria. J Niger Environ Soc 2:247-256

FAO (1983) Compilation of legal limits for hazardous substances in fish and fishery products. Food and Agriculture Organisation (FAO) Fishery Circular, No. 464, pp 5-100

Fatma ASM (2008) Bioaccumulation of selected metals and histopathological alterations in Tissues of Oreochromis niloticus and Lates niloticus from Lake Nasser, Egypt. Global Vet 2(4):205-218

Fergusson JE (1990) The heavy elements: chemistry, environmental impact and health effects. Pergamon Press, New York 614 p
Fernandes C, Fontainhas-Fernandes A, Peixoto F, Salgado MA (2007) Bioaccumulation of heavy metals in Liza saliens from the Esmoriz-Paramos coastal lagoon, Portugal. Ecotoxicol Environ Saf 66(3):426-431

Fernandes C, Fontaínhas-Fernandes A, Cabral D, Salgado MA (2008) Heavy metals in water, sediment and tissues of Liza saliens from Esmoriz-Paramos lagoon, Portugal. Environ Monit Assess 136:267-275

Forstner U, Wiltman GTW (1983) Metal pollution in aquatic environment. Springer, Berlin

Friday K, Ekpete O, Loveday I (2009) Seasonal variation of Cd, Ni, $\mathrm{Cu}$ and $\mathrm{Pb}$ in catfish, sediment and water samples from ipo stream in Ikwerre District of Rivers State, Nigeria. J Appl Sci Environ Manag 13:63-67

FSA (2005) Arsenic in fish and shellfish. Food Surveillance Information Sheet, Food Standard Agency, 82/05

Gan JL, Jia XP, Lin Q, Li CH, Wang ZH, Zhou GJ, Wang XP, Cai WG, Lu XY (2000) A primary study on ecological risk caused by the heavy metals in coastal sediments. J Fish China 24:533-538 (in Chinese)

Garcia-Montelongo F, Díaz C, Galindo L, Larrechi MS, Rius X (1994) Heavy metals in three fish species from the coastal waters of Santa Cruz de Tenerife (Canary Islands). Scientia Marina 58:179-183

Håkanson L (1980) An ecological risk index for aquatic pollution control of sediment ecological approach. Water Res 14:975-1000

Higueras P, Oyarzun R, Oyarzun J, Maturana H, Lillo J, Morata D (2004) Environmental assessment of copper-gold-mercury mining in the Andacollo and Punitaqui districts, northern Chile. Appl Geochem 19(11):1855-1864

Hilton J, Davison W, Ochsenbein U (1985) A mathematical model for analysis of sediment coke data. Chem Geol 48:281-291

Hope BK (2006) An examination of ecological risk assessment and management practices. Environ Int 32(8):983-995

Hough RL, Breward N, Young SD, Crout NM, Tye AM, Moir AM, Thornton L (2004) Assessing potential risk of heavy metal exposure from consumption of home-produced vegetables by urban populations. Environ Health Perspect 112:215-221

Hu GD, Wu W, Chu JH, Sun ZZ, Chen JC (2002) Water pollution and its toxicity to fishes in the major areas of the lower researches of the Yangtze River. Acta Hydrobiol Sin 26(6):635-640

IS (2012) Standards for drinking water. Bureau of Indian Standards (IS 10500), New Delhi, India

Jain SC, Mehta SC, Kumar B, Reddy AR, Nagaratnam A (1995) Formulation of the reference Indian Adult: anatomical and physiological data. Health Phys 68:509-522

JECFA (1999) Reports of the 53rd meeting of the Joint FAO/WHO Expert Committee on Food Additives (JECFA). JECFA/53/TRS. Rome, Italy

JECFA (2003) Summary and conclusions of the 61st meeting of the Joint FAO/WHO Expert Committee on Food Additives (JECFA). JECFA/61/SC. Rome, Italy

Jefferies DJ, Freestone P (1984) Chemical analysis of some coarse fish from a Suffolk River carried out as part of the preparation for the first release of captive-bred otters. J Otter Trust 18:17-22

Joint FAO/WHO (1999) Expert committee on food additives, summary and conclusions, In: 53rd Meeting, Rome, 1-10 June

Jordao CP, Pereira MG, Bellato CR, Pereira JL, Matos AT (2002) Assessment of water systems for contaminants from domestic and industrial sewages. Environ Monit Assess 79:75-100 
Karadede H, Unlu E (2000) Concentrations of some heavy metals in water, sediment and fish species from the Ataturk Dam Lake (Euphrates), Turkey. Chemosphere 41:1371-1376

Larsson A, Haux C, Sjobeck M (1985) Fish physiology and metal pollution: results and experience from laboratory and field studies. Ecotoxicol Environ Saf 9:250-281

Liu F, Ni H, Chen F, Luo Z, Shen H, Liu L, Wu P (2012) Metal accumulation in the tissues of grass carps (Ctenopharyngodon idellus) from fresh water around a copper mine in Southeast China. Environ Monit Assess 184:4289-4299

Mayes WM, Potter HAB, Jarvis AP (2010) Inventory of aquatic contaminant flux arising from historical metal mining in England and Wales. Sci Total Environ 408(17):3576-3583

Miller JC, Miller JN (1989) Statistics for analytical chemistry, 2nd edn. Ellis, Horwood, New York

Moiseenko TI, Kudryavtseva LP (2001) Trace metal accumulation and fish pathologies in areas affected by mining and metallurgical enterprises in the Kola Region, Russia. Environ Pollut 114(2):285-297

Nriagu JO, Wong HK, Lawson G, Daniel P (1998) Saturation of ecosystems with toxic metals in Sudbury basin, Ontario, Canada. Sci Total Environ 223:99-117

Obasohan EE, Eguavoen OI (2008) Seasonal variations of bioaccumulation of heavy metals in a freshwater fish (Erpetoichthys calabaricus) from Ogba River, Benin City, Nigeria. African J of Gen Agric 4:153-163

Odiete WO (1999) Environmental Physiology of animals and pollution. Diversified resources, Lagos

Palaniappan PLRM, Karthikeyan S (2009) Bioaccumulation and depuration of chromium in the selected organs and whole body tissues of freshwater fish Cirrhinus mrigala individually and in binary solutions with nickel. J Environ Sci 21(2):229-236

Peerzada N, McMorrow L, Skiliros S, Guinea M, Ryan P (1990) Distribution of heavy metals in Gove Harbour, Northern Territory, Australia. Sci Total Environ 92:1-12

Porstner U (1989) Lecture notes in earth sciences (contaminated sediments). Springer, Berlin, pp 107-109

Pourang N, Dennis JH, Ghourchian H (2005) Distribution of heavy metals in Penaeus Semisulcatus from Persian Gulf and possible role of metallothionein in their redistribution during storage. Environ Monit Assess 100:71-88

Preston MR, Chester R (1996) Chemistry and pollution of the marine environment. In: Harison RM (ed) Pollution: causes, effects and control, 3rd edn. Royal Society of Chemistry, UK, pp 26-51

Protasowicki M (1985) Comparison of techniques of fish sample preparation for heavy metals analysis by flame AAS. In Proceedings of the 24th CSI, Garmisch-Partenkirchen, 3(Th I046), pp 548-549

Prusty BG, Sahu KC, Godgul G (1994) Metal contamination due to mining and milling activities at the Zawar zinc mine, Rajasthan, India: contamination of stream sediments. Chem Geol 112:275-292

Pyle GG, Rajotte JW, Couture P (2005) Effects of industrial metals on wild fish populations along a metal contamination gradient. Ecotoxicol Environ Saf 61:287-312

Radojevic M, Bashkin VN (1999) Practical environmental analysis. Royal Society of Chemistry, London, pp 154-155

Rashed MN (2001) Monitoring of environmental heavy metals in fish from Nasser Lake. Environ Int 27:27-33

Reinfelder JR, Fisher NS, Luoma SN, Nichols JW, Wang WX (1998) Trace element trophic transfer in aquatic organisms: a critique of the kinetic model approach. Sci Total Environ 219:117-135

Rejomon G, Nair M, Joseph T (2010) Trace metal dynamics in fishes from the southwest coast of India. Environ Monit Assess $167: 243-255$
Riba I, Blasco J, Jimenez-Tenorio N, DelValls TA (2005) Heavy metal bioavailability and effects: I. Bioaccumulation caused by mining activities in the Gulf of Cadiz (SW, Spain). Chemosphere 58(5):659-669

Sapkota A, Sapkota AR, Kucharski M, Burke J, McKenzie S, Walker $P$ et al (2008) Aquaculture practices and potential human health risks: current knowledge and future priorities. Environ Int 34(8):1215-1226

Sivaperumal P, Sankar TV, Viswanathan Nair PG (2007) Heavy metal concentrations in fish, shellfish and fish products from internal markets of India vis-a-vis international standards. Food Chem 102:612-620

Song B, Lei M, Chen T, Zheng YM, Xie YF, Li XY, Gao D (2009) Assessing the health risk of heavy metals in vegetables to the general population in Beijing, China. J Environ Sci (China) 21:1702-1709

Storelli MM (2008) Potential human health risks from metals ( $\mathrm{Hg}$, $\mathrm{Cd}$, and $\mathrm{Pb}$ ) and polychlorinated biphenyls (PCBs) via seafood consumption: estimation of target hazard quotients (THQs) and toxic equivalents (TEQs). Food Chem Toxicol 46:2782-2788

Subramanian R, Sukumar A (1988) Biological reference materials and analysis of toxic elements. Fresenius' Zeitschrift für Analytische Chemie 332:623-626

Subramanian V, Van't Dack L, Van Grieken R (1985) Chemical composition of river sediments from the Indian Sub-continent. Chem Geol 48:271-279

Tarras-Wahlberg NH, Flachier A, Lane SN, Sangfors O (2001) Environmental impacts and metal exposure of aquatic ecosystems in rivers contaminated by small scale gold mining: the Puyango River basin, southern Ecuador. Sci Total Environ 278(1-3):239-261

Tekin-Ozan S (2008) Determination of heavy metal levels in water, sediment and tissues of tench (Tinca tinca L., 1758) from Beysehir Lake (Turkey). Environ Monit Assess 145:295-302

Turekian KK, Wedepohl KH (1961) Distribution of the elements in some major units of the earth's crust. Am Geol Soc Bull 72:175-182

UNEP/FAO/IAEA/IOC (1984) Sampling of selected marine organisms and sample preparation for trace metal analysis. Reference methods for Marine pollution studies No. 7, Rev 2

USEPA (1989) Health effect assessments summary tables (HEAST) and user's guide, Office of Emergency and Remedial Response, United States Environmental Protection Agency, Washington, DC, USA

USEPA (1996) EPA Method 3052: Microwave assisted acid digestion of siliceous and organically based matrices. U.S. Environmental Protection Agency, Office of Solid Waste and Emergency Response, U.S. Government Printing Office, Washington, DC

USEPA (2011) Risk-based concentration table. United States Environmental Protection Agency, Washington, DC, USA

Uysal K, Emre Y, Köse E (2008) The determination of heavy metal accumulation ratios in muscle, skin and gills of some migratory fish species by inductively coupled plasma-optical emission spectrometry (ICP-OES) in Beymelek Lagoon (Antalya/Turkey). Microchem J 90:67-70

Vicente-Martorell JJ, Galindo-Riaño MD, García-Vargas M, Granado-Castro MD (2009) Bioavailability of heavy metals monitoring water, sediments and fish species from a polluted estuary. J Hazard Mater 15(2-3):823-836

Wang XL, Sato T, Xing BS, Tao S (2005) Health risks of heavy metals to the general public in Tianjin, China via consumption of vegetables and fish. Sci Total Environ 350:28-37

Wang Y, Yang Z, Shen Z, Tang Z, Niu J, Gao F (2011) Assessment of heavy metals in sediments from a typical catchment of the Yangtze River, China. Environ Monit Assess 172:407-417 
Wayne RO (1990) A physical explanation of the lognormality of pollutant concentrations. J Air Waste Manag Assoc 40:1378-1383

WHO (2004) Guidelines for drinking water quality, vol 1, 6th edn. Geneva, World Health Organization, pp 80-83

Yi Y, Yang Z, Zhang S (2011) Ecological risk assessment of heavy metals in sediment and human health risk assessment of heavy metals in fishes in the middle and lower reaches of the Yangtze River basin. Environ Pollut 159:2575-2585

Yilmaz F (2006) Bioaccumulation of heavy metals in water, sediment, aquatic plants and tissues of Cyprinus carpio from Kýzýlýrmak. Fresenius Environ Bull 15(5):360-369

Yilmaz AB, Dogan M (2008) Heavy metals in water and in tissues of Himri (Carasobarbus luteus) from Orontes (Asi) River, Turkey. Environ Monit Assess 144:437-444

Yilmaz AB, Yllmaz L (2007) Influences of sex and seasons on levels of heavy metals in tissues of green tiger shrimp (Penaeus semisulcatus de Harur. 1844). Food Chem 101:1664-1669
Yusof AM, Yanta NF, Wood AKH (2004) The use of bivalves as bioindicators in the assessment of marine pollution along a coastal area. J Radioanal Nucl Chem 259(1):119-127

Zheng N, Wang Q, Zhang X, Zheng D, Zhang Z, Zhang S (2007) Population health risk due to dietary intake of heavy metals in the industrial area of Huludao City, China. Sci Total Environ 387:96-104

Zheng N, Wang QC, Liang ZZ, Zheng DM (2008) Characterization of heavy metal concentrations in the sediments of three freshwater rivers in Huludao City, Northeast China. Environ Pollut 154:135-142

Zrnčić S, Oraić D, Ćaleta M, Mihaljević Ž, Zanella D, Bilandžić N (2012) Biomonitoring of heavy metals in fish from the Danube River. Environ Monit Assess. doi:10.1007/s10661-012-2625-x. 25th April 2012

Zyadah MA (2005) Impact assessment of heavy metals on some fishes and aquatic macrophytes along El-Salam Canal, Egypt. Egypt J Aquat Biol Fish 9:505-521 